\title{
悪性腺腫と鑑別を要する分葉状頸管腺過形成の 細胞の見方と捉え方
}

\author{
畠 榮 1 ） 三上 芳喜 ${ }^{2)}$ 秋山 隆 1) 定平 吉都 1) \\ 川崎医科大学附属病院病院病理部 1), 京都大学医学部附属病院病理部 2)
}

Key words : Adenoma malignum — Lobular endocervical glandular hyperplasia- Cytology - Uterine cervix

目的：覀性腺腫と鑑別を要する分葉状頸管腺過形成 lobular endcervical glandular hyperplasia（以下 LEGH）の細胞学的特徵を明らかにするため, 正常頸管腺, 腺異形成, 上皮内腺癌などの子宮頸部腺系病変 の細胞像と比較検討した。

方法：頸部スメアで異型腺細胞が認められた 85 例の子宮頸部腺病変を対象として, 背景, 細胞の出現形 態，核所見ならびに細胞質内粘液の染色性などを検討した．また，Ioffe らによるスコアリング・システムに よる半定量的な異型腺病変の評価法の意義についても検討した.

結果：全集塊中のシート状大型集塊の出現頻度は腺異形成 50\%, LEGH 42\%, 覀性腺腫 $21 \%$ であった。2, 3 層の核重積を示す柵状集塊は上皮内腺癌 $17 \%$ ，微小浸潤腺癌 $11 \%$ ，LEGH 5\%，悪性腺腫 $12 \%$ であった. 4 層以上の重積は上皮内腺癌 $9 \%$, 微小浸潤腺癌 $35 \%$ の頻度で認められたのに対して, LEGH, 覀性腺腫では $0.3 \%, 2 \%$ にすぎなかった。核異型は LEGH では認められなかったが，悪性腺腫では明らかな核形不整，ク ロマチン構造の粗造化, 核小体の明瞭化が認められた。核内細胞質内封入体は LEGH の $1 / 3$, 悪性腺腫の $2 / 3$ の症例で認められた。 LEGH と悪性腺腫では細胞質内粘液が黄色から淡黄色の色調を呈していたのに対 して, 他の病変ではへマトキシリン好性であった. Ioffeらの基準に準拠すると腺異形成, LEGH, 悪性腺 腫，上皮内腺癌抢よび浸潤腺癌のスコアの平均值はそれぞれ $3.5,3.8,4.2,6$ あった。

結論：LEGH ならびに悪性腺腫は黄色調を呈する細胞質内粘液と核内細胞質内封入体がみられる点で他の 頸部腺病変から区別される. 両者の判別には細胞集塊の形態と核の異型性，すなわち核形不整㧠よび大小不 同，クロマチン構造の粗造化，核小体の明瞭化，などが重要であると考えられた。

I. はじめに

Cytology discrimination point of adenoma malignum and lobular endocervical glandular hyperplasia

Sakae HATA ${ }^{1)}$, C.T., Yoshiki MIKAMI'), M.D., Takashi AKIYA$\mathrm{MA}^{1)}$, M.D., Yoshito SADAHIRA ${ }^{1)}$, M.D.

1) Department of Pathology, Kawasaki Medical School Hospital

${ }^{2)}$ Division of Histopathology, Kyoto University Graduate School of Medical Science

論文別刷請求先 $\overline{7} 701-0192$ 岡山県倉敷市松島 577 川崎医科大 学附属病院病院病理部畠榮

平成 17 年 5 月 2 日受付

平成 17 年 11 月 28 日受理

\section{策}


HIK1083 陽性所見で特徵づけられる胃型形質を有するこ とが明らかとなり ${ }^{2)}$ ，かつ黄色調の細胞質内粘液を有する 腺細胞が頸部スメアで認められることも確認されるに至っ た ${ }^{3)}$. そこで今回われわれは悪性腺腫の診断の鍵となる所 見を明らかにするため，正常頸管腺，腺異形成，上皮内腺 癌などの子宮頸部腺病変の細胞像を比較検討した。

\section{II. 材料と方法}

子宮頸部擦過細胞診検体ならびに子宮頸管内ブラシ細胞 診検体で異型腺細胞が検出され，かつ病理組織学的に診断 が確定された 88 例（非腫瘍性病変 56 例，腺異形成 6 例, 上皮内腺癌 9 例, 微小浸潤腺癌 2 例, LEGH 9 例ならびに悪 性腺腫 6 例）を対象として，(1) 背景，（2）腫瘍細胞の出 現形態，（3）核所見，（4）細胞質内粘液の染色性，を中心 に検討した．対照として正常頸管腺 5 例ならびに子宮頸部 浸潤腺癌（高分化一低分化型腺癌）12 例を用いた。また， Ioffe ら 4) が提唱した腺異形成および上皮内腺癌の組織学 的判別を目的としたスコアリング・システムの一部を細胞 診断用に改変して検討した，すなわち，細胞所見を，(1） 核の重積性，（2）核の異型度，（3）核分裂像出現率を0 3 の 4 段階に分け，数字を合計してスコア化した. 背景な らびに子宮頸部腺細胞内の黄色調粘液の有無についても半 定量的に評価した（Table 1).

\section{III. 結果}

\section{1. 子宮頸部腺系病変の細胞像}

1）背景ならびに粘液の染色性

腺異形成, 上皮内腺癌, 微小浸潤腺癌, LEGH, 悪性腺 腫の背景は全例清明であった. LEGH および悪性腺腫の背 景は黄色調から黄褐色調の粘液が種々の程度で認められ た。構成細胞は既存の頸管粘液腺細胞と類似しており，全 例で細胞質内粘液は黄色〜淡褐色調を呈していた (Photo. $1 \mathrm{a} \sim \mathrm{d}$ ). 腺異形成, 上皮内腺癌, 微小浸潤腺癌, 分化型腺癌や浸潤腺癌の一部では細胞質内粘液の染色性は ヘマトキシリン好性であった。

2) 出現形態ならびに頻度

おのおのの病変における細胞集塊の形態的特徴と全集塊 中の出現頻度の平均值を Table 2 に示す. シート状の大型 集塊の出現率は腺異形成で $50 \%$, LEGH で $42 \%$, 悪性腺腫 で $21 \%$ であった. 細胞集塊辺縁の全周を高円柱状の粘液 細胞で覆われた大型シート状集塊はLEGH，悪性腺腫の全 例でみられたが，他の腺系病変では認められなかった。一 方, 平面的な細胞集塊の一部に小腺腔を有するものは LEGH 9 例中 4 例 (44\%) に出現していたが（Photo. 2 a〜 c), 悪性腺腫や他の腺系病変では認められなかった。柵状 配列や核下部に細胞質を伴った羽毛状配列は非腫瘍性例で は 56 例中 28 例 $(50 \%)$ の症例にみられたが，上皮内腺癌， 微小浸潤腺癌, 悪性腺腫, LEGH では全例に認められた. 2，3 層の核偽重積を示す柵状集塊は上皮内腺癌 16.7\%，微 小浸潤腺癌 $11.3 \%$, LEGH 6.3\%，悪性腺腫 12.1\%の頻度で

Table 1 Diagnosis of modified Ioffe scoring

\begin{tabular}{|c|c|}
\hline Feature & Score \\
\hline \multicolumn{2}{|l|}{ Stratification } \\
\hline None (no stratification or without cord structure) & 0 \\
\hline Mild (up to one third of epithelial thickness) & 1 \\
\hline Moderate (up to two thirds of epithelial thickness) & 2 \\
\hline Up to luminal surface & 3 \\
\hline \multicolumn{2}{|l|}{ Nuclear atypia } \\
\hline As normal & 0 \\
\hline Small (normal size) or slightly enlarged uniform nuclei, minimal hyperchromasia, dispolarity, no nucleoli & 1 \\
\hline Nuclear enlargement (up to $3 \times$ normal), moderate anisocytosis, hyperchromasia, dispolarity, occasional small nucleoli & 2 \\
\hline Large nuclei $(>3 \times$ normal $)$, marked anisocytosis, hyperchromasia, severe dispolarity, frequent prominent nucleoli & 3 \\
\hline \multicolumn{2}{|l|}{ Mitoses and apoptoses } \\
\hline None & 0 \\
\hline Positive & 1 \\
\hline \multicolumn{2}{|l|}{ Golden mucin in cord-like glandular cells } \\
\hline None & 0 \\
\hline Positive & 1 \\
\hline
\end{tabular}

Total score : $0 \sim 3=$ benign, $4 \sim 5=$ endocervical glandular dysplasia (EGD), $6 \sim 8=$ adenocarcinoma in situ 
Table 2 Cytological features in endocervical glandular lesions (percentage in total number of clusters)

\begin{tabular}{lrrrrrc}
\hline \hline & EGD & AIS & MIA & LEGH & AM & Adeno-carcinoma \\
\hline Monolayered sheet & 50.2 & 8.5 & 2.4 & 41.5 & 21.3 & 7.2 \\
No stratification & 23.4 & 7.5 & 3.4 & 17.7 & 13.3 & 1.8 \\
Stratification $(2 \sim 3)$ & 3.6 & 16.7 & 11.3 & 6.3 & 12.1 & 1.2 \\
Stratification $(4<)$ & 0.2 & 9 & 34.7 & 0.3 & 2 & 2.8 \\
Feathering & 9.1 & 18.2 & 9.4 & 1.5 & 3.7 & 3.5 \\
Acini/rosettes & 0.6 & 6.9 & 5.1 & 1 & 0.5 & 2.8 \\
Cord structure & 1 & 2.4 & 1.1 & 0.6 & 0 & 4.2 \\
3D clusters & 0 & 1.4 & 0.3 & 0 & 0 & 7.7 \\
\hline
\end{tabular}

EGD : endocervical glandular dysplasia, AIS : adenocarcinoma in situ, MIA : microinvasive adenocarcinoma, LEGH : lobular endocervical glandular hyperplasia, AM : adenoma malignum

Table 3 Mean component scores in each diagnostic category.

\begin{tabular}{lcccc}
\hline \multicolumn{1}{c}{ Diagnosis } & Stratification & Nuclear atypia & Yellow mucin & Total \\
\hline Benign/reactive $(\mathrm{n}=56)$ & 0.69 & 1.19 & 0 & 1.88 \\
EGD $(\mathrm{n}=6)$ & 1.66 & 1.83 & 0 & 3.49 \\
LEGH $(\mathrm{n}=9)$ & 1.54 & 1.23 & 1 & 3.77 \\
AM $(\mathrm{n}=6)$ & 1.58 & 1.66 & 1 & 4.24 \\
AIS $(\mathrm{n}=9)$ & 3 & 3 & 0 & 6 \\
Adenocarcinoma $(\mathrm{n}=12)$ & 3 & 3 & 0 & 6 \\
\hline
\end{tabular}

EGD : endocervical glandular dysplasia, LEGH : lobular endocervical glandular hyperplasia, AM : adenoma malignum, AIS : adenocarcinoma in situ

あった４層以上は上皮内腺癌 $9 \%$ ，微小浸潤腺癌 $34.7 \%$ の 頻度で認められたが LEGH 0.3\%，悪性腺腫 2.0\%とほとん ど認められなかった．対照に用いた正常頸部腺細胞は 5 , 6 個程度の細胞よりなる柵状配列としてみられたが，核の 偽重積性は認められなかった。羽毛状集塊の出現率は非腫 瘍性病変 $9.1 \%$ ，上皮内腺癌 $18.2 \%$ ，微小浸潤腺癌 $9.4 \%$ に対 して LEGH，悪性腺腫では 1.5 3.7\% であった．血管結合 組織を芯とする真の乳頭状集塊はLEGHではみられな かったが，悪性腺腫では細い血管結合組織を芯とする乳頭 状構造が認められた。 その細胞密度は高く, 乳頭の太さは 不均一で，先端部の腫大が認められた（Photo. $3 \mathrm{a}, \mathrm{b}$ ).

3) 核所見

子宮腺系病変で栅状配列の核には紡錘形核と, 楕円形の 核を有するものの 2 種類があることが明らかとなった．紡 錐形核は上皮内腺癌や腺異形成で認められた。一方, 類円 形は LEGH で高頻度に認められた。

LEGH の核の大きさは均一でかつ小型で, 円形〜類円形 を呈し，核クロマチンは微細顆粒状の分布も一様であっ た。核小体は欠如ないし微細なものが 1 個程度認められる のみであった。これに対して悪性腺腫の核は不整形で, 顕 著な大小不同，核クロマチン構造の粗造化や核小体の明瞭 化が認められた（Photo. $4 \mathrm{a} \sim \mathrm{d}$ )。細胞質成分が核膜に囲
まれた状態で核内に存在し，その境界が明膫かつ境界部の 内側が平滑で，外側にクロマチンの凝集が認められるもの を核内細胞質封入体と定義して観察した．LEGH では 9 例 中 3 例 $(33.3 \%)$ で明膫な核内細胞質封入体が認められた (Photo. $5 \mathrm{a} \sim \mathrm{c}$ )．悪性腺腫でも 6 例中 4 例（66.6\%）で同様 の封入体が認められた。これに対して，他の腺系病変では 封入体は認められなかった。 な打，正常頸管腺細胞も約 3000 例中 1 例（未発表デー夕）の頻度で核内細胞質封入体 が観察された。

2. スコアリングを用いた子宮頸部腺系病変の評価結果 Ioffe らのスコアリング・システムでの核の偽重積の平 均值は非腫瘍性病変 0.69 , 腺異形成 1.66, LEGH 1.54, 悪 性腺腫 1.58 , 上皮内腺癌以上 3 であった。核異型度は非腫 瘍性病変 1.99 , 腺異形成 1.83, LEGH 1.23, 悪性腺腫 1.66 , 上皮内腺癌以上 3 であった。 な抢今回検討した症例では核 分裂像やアポトーシス像を認識することはできなかった。 また胃幽門腺化生性病変の LEGH ならびに悪性腺腫では 黄色〜淡褐色調に染色される粘液が認められスコア 1 を加 えた。スコア合計は非腫瘍性病変 1.88, 腺異形成 3.49 , LEGH 3.77, 覀性腺腫 4.24, 上皮内腺癌以上 6 であった (Table 3)。しかし，線毛細胞化生（卵管上皮化生）を示 す柵状配列集塊では核の偽重積性（スコア3), 核の異型 
度（スコア 2)，核分裂像やアポトーシス像はスコア0で， 合計は 5 であった.

\section{IV. 考察}

LEGH は偶発所見として認められることもあるが，高度 な例では著明な水様帯下がみられ, CT や MRI で頸部に多 数の小震胞が描出されることから，臨床的にも悪性腺腫を 疑われることがある ${ }^{5,6)}$. 近年頸部スメアで黄色調を呈す る細胞質内粘液を有する高円柱細胞の柵状ないし大型シー 卜状集塊が悪性腺腫に特徴的でかつ診断的価值のある所見 であるという報告が相次いだが7 10)。われわれの検討で はこれらの所見はLEGH においてもみられることが確認 された．このことは，悪性腺腫として検討され，報告され てきた症例のなかにLEGH が含まれていた可能性を示し ている. LEGH と悪性腺腫の判別は, 通常の腺細胞の良悪 性を判断するために用いられる基準，すなわち核の大小不 同，核形不整，重積の有無などに基づいてなされる必要が ある．粘液の色調はあくまで鑑別診断を LEGH および悪 性腺腫の 2 つに絞り込むための参考所見ととらえるべきで あろう。核内細胞質封入体も興味ある所見であるが，いず れにおいても認められたことから，両者の判別には役に立 たないと考えられた.

子宮頸部ブラッシングなどにより採取された材料中には 柵状配列が認められるため, 核偽重積性を重視するIoffe ら4)のスコアリング・システムはある程度細胞診にも応
用可能と考えられた．このシステムは核の偽重積と核異型 を数值化して評価するため，再現性のある方法と考えられ る. 今回の評価ではスコアの平均值は非腫瘍性病変 1.88 , 腺異形成 3.49, LEGH 3.77, 悪性腺腫 4.24, 上皮内腺癌お よび通常の浸潤腺癌では 6 であった，上皮内癌腺癌や浸潤 腺癌ではおおむね核偽重積が 4 層以上と顕著で，かつ核の 位置が円柱細胞の丈の上 $1 / 3$ に達しており，組織診におけ るのと同様の評価を行うことが可能であった。しかし， LEGH や悪性腺腫では豊富な細胞質内粘液の存在によって 核が基底膜側に圧迫されており，核の偽重積が軽度である 傾向がみられた。重積のスコアの平均值は LEGH で 1.54 ,

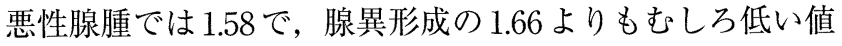
であった。この結果からも，LEGH と悪性腺腫を鑑別する ためのポイントが細胞集塊の形態，核異型度であるといえ る (Table 4). 具体的には, LEGH の核の大きさは均一か つ小型で, 円形ないし類円形を呈し, 核クロマチンは微細 顆粒状で均一に分布している。核小体は欠如ないし微細な ものが 1 個認められる程度である。これに対して悪性腺腫 の核形は不整で, 大小不同が顕著であり, 核クロマチン構 造の粗造化や核小体が明瞭である。

臨床的に悪性腺腫が疑われながらも診断の確定が困難な 場合の臨床的対応については，現在十分なコンセンサスは 得られていないが，実際にはより頻度の高い疾患であり， LEGH であることが後に判明することのほうが多いと考え られる. LEGH は内子宮口付近に好発するため, 頸管内ブ ラッシング採取法などを用いて内子宮口側部より積極的細

Table 4 Cytologic findings in LEGH VS adenoma malignum

\begin{tabular}{|c|c|c|}
\hline & LEGH & Adenoma malignum \\
\hline Golden mucin & ++ & ++ \\
\hline Tumor diathesis & - & - \\
\hline Inflammation & $-\sim \pm$ & $-\sim \pm$ \\
\hline Quantity of cells & $+\sim+++$ & $+\sim+++$ \\
\hline Cord structure & ++ & + \\
\hline 3D clusters & - & - \\
\hline Monolayered sheet & $+\sim++$ & $+\sim++$ \\
\hline Multilayered strips & $-\sim \pm$ & $-\sim+$ \\
\hline Acini/rosettes & $-\sim+$ & $-\sim+$ \\
\hline Feathering & $-\sim+$ & $-\sim+$ \\
\hline \multicolumn{3}{|l|}{ Nuclear features } \\
\hline Nuclear enlargement & + & $+\sim++$ \\
\hline Irregular nuclear contour & - & + \\
\hline Prominent nucleoli & - & + \\
\hline Mitoses & - & $-\sim \pm$ \\
\hline Hyperchromasia & $-\sim \pm$ & + \\
\hline Chromatin texture & mildly coarse & mildly/moderate coarse \\
\hline Nuclear to cytoplasmic ratio & slightly/mildly increased & mildly increased \\
\hline Overlapping nuclei & - & + \\
\hline Loss of polarity & - & + \\
\hline
\end{tabular}


胞を採取することが診断に不可欠である ${ }^{2,11)}$.しかし，細 胞診にも限界があることを理解し，婦人科医や放射線科医 との情報交換, 組織診断との相関を確認することが重要で あると考えられる。

\section{Abstract}

Objective : We reviewed the cytologic features of benign endocervical glandular cells, glandular dysplasia, and adenocarcinoma in situ (AIS) to determine diagnostic features of adenoma malignum and lobular endocervical glandular hyperplasia (LEGH).

Study Design: We studied the appearance of cell clusters and backgrounds, cell morphology, including nuclear features and staining patterns of intracytoplasmic mucin on Pap smears, in 85 cases of endocervical glandular lesions. We also studied the validity of histological scoring for discriminating between glandular dysplasia and adenocarcinoma in situ, proposed by Ioffe et al., in cytological diagnosis. The frequency of large monolayered sheets of cells in adenoma malignum, was $21 \%$, in glandular dysplasia $50 \%$, and in LEGH $42 \%$. Clusters showing two to three layers of nuclear pseudostratification were seen in $17 \%$ of AIS, $11 \%$ of microinvasive adenocarcinoma, $5 \%$ of LEGH, and $12 \%$ of adenoma malignum. Clusters with more than four layer nuclear pseudostratification were only $0.3 \%$, and $2 \%$ in LEGH and adenoma malignum. It was $9 \%$ in AIS and $35 \%$ in microinvasive adenocarcinoma. Irregular nuclear contour, coarse chromatin texture, and prominent nucleoli were observed in adenoma malignum. We saw no distinct nuclear abnormalities in LEGH, however in about $1 / 3$ of LEGH and $2 / 3$ of adenoma malignum, intranuclear cytoplasmic inclusions were also seen. Yellowish intracytoplasmic mucin was identified in both LEGH and adenoma malignum. Following Ioffe et al., the combined score was 3.5 in glandular dysplasia, 3.8 in LEGH, 4.2 in adenoma malignum, and 6 in adenocarcinoma.

Conclusion: LEGH and adenoma malignum are distinguished from other benign endocervical glandular lesion by yellowish intracytoplasmic mucin and intranuclear cytoplasmic inclusion. Adenoma malignum is distinguished from LEGH by the morphology of cell clusters, distinct nuclear abnormalities, i.e., irregular shape and size variation, coarse chromatin architexture and prominent nucleoli.

\section{文献}

1) Nucci, M.R., Clement, P.B., Young, R.H. Lobular endocervical glandular hyperplasia, not otherwise specified : a clinicopathologic analysis of thirteen cases of a distinctive pseudoneoplastic lesion and comparison with fourteen cases of adenoma malignum. Am J Surg Pathol $1999 ; 23: 886 \sim 891$.

2) Mikami, Y., Hata, S., Melamed, J., Fujiwara, K., Manabe, T. Lobular endocervical glandular hyperplasia is a metaplastic process with a pyloric gland phenotype histopatholology. $2001 ; 139: 364 \sim 372$.

3) Hata, S., Mikami, Y., Manabe, T. Diagnostic significance of endocervical glandular cells with "golden-yellow" mucin on pap smear. Diagn Cytopathol. $2002 ; 27: 80 \sim 84$.

4) Ioffe, O.B., Sagae, S., Moritani, S., Dahmoush, L., Chen, T.T., Silverberg, S.G. Proposal of a new scoring scheme for the diagnosis of noninvasive endocervical glandular lesions. Am J Surg Pathol. $2003 ; 27$ (4) : 452 460.

5) Mikami, Y., Hata, S., Fujiwara, K., Imajo, Y., Kohno, I., Manabe, T. Florid endocervical glandular hyperplasia with intestinal and pyloric gland metaplasia : worrisome benign mimic of "adenoma malignum". Gynecol Oncol $1999 ; 74: 504 \sim$ 511.

6) Yoden, E., Mikami, Y., Fujiwara, K., Kohno, I., Imajo, Y. Florid endocervical glandular hyperplasia with pyloric gland metaplasia : a radiologic pitfall. J Comput Assist Tomogr 2001 ; $25: 94 \sim 97$.

7）佐々木綾子, 小幡憲郎, 竹内正七, 永井絵津子. 子宮頸部 Adenoma malignum の細胞診とその臨床病理学的検討. 日臨 細胞誌 $1987 ; 26: 35 \sim 42$.

8) Szyfelbein, W.M., Young, R.H., Scully, K.E. Adenoma mahgnum of the cervix. cytologic findings. Acta Cytologica $1984 ; 28: 691 \sim 698$.

9) Ishii, K., Katsuyama, T., Ota, H., Watanabe, T., Matsuyama, I., Tsuchiya, S., et al. Cytologic and cytochemical features of adenoma malignum of the uterine cervix. Cancer 1999 ; $87: 245 \sim 253$.

10）荒井祐司，芳賀厚子，平井康夫，秋山 太，都竹正文，山内 一弘・ほか. 子宮頸部腺病 Adenoma malignum の細胞像につ いて. 日臨細胞誌 $1999 ; 38: 1 \sim 5$.

11）畠 笨，秋山 隆，伊禮 功，定平吉都. 子宮頸部の腺系 病変の細胞診一子宮頸部上皮内腺系病変の見方ととらえ方に ついて一。 日本臨床細胞学会中国四国連合会会報 2004； $19: 125 \sim 129$.

\footnotetext{
1) Nucci, M.R., Clement, P.B., Young, R.H. Lobular endocervical
} 


\section{写真説明}

Photo. 1 Cytology and histopathology of LEGH and adenoma malignum. The cytoplasm of LEGH and adenoma malignum cells is yellowish. (a, b) Yellowish mucus in LEGH. Pseudostratified elongated nuclei with similar patterns of chromatin granularity are visible. (Papanicolaou staining; a $\times 100, \mathrm{~b} \times 100$ ). (c, d) Yellowish mucus in adenoma malignum. Oval or elongated nuclei with an abundance of evenly distributed but coarsely granular chromatin. (Papanicolaou staining; $c \times 40, d \times 100$ ).

Photo. 2 Cytology and histopathology of LEGH. (a, b) The LEGH appears as a sheet of crowded cells with round or oval nuclei and some acinal structures consisting of yellowish mucus-producing cells. (Papanicolaou staining ; $\mathrm{a} \times 40, \mathrm{~b} \times 100)$. (c) Immunohistochemistry for M-GGMC-1, which reacts with pyloric gland mucin $(\times 20)$.

Photo. 3 Papillary patterns in adenoma malignum. (a, b) Fingerlike projections (papillae) in adenoma malignum. (a : Papanicolaou staining, $\times 20 ; \mathrm{b}:$ HE staining, $\times 20$ ).

Photo. 4 Nuclear findings for LEGH and adenoma malignum. (a, b) LEGH : Round to oval, occasionally elongated, nuclei with fine granular chromatin and small nucleoli (Papanicolaou staining; a $\times 40, \mathrm{~b} \times 100$ ). (c, d) Adenoma malignum : Enlarged variably-sized round to oval nuclei with prominent nucleoli and hyperchromatic chromatin (Papanicolaou staining; $\mathrm{c}, \mathrm{d} \times 100$ ).

Photo. 5 Intranuclear cytoplasmic inclusions in LEGH. The inclusions are sharply defined and completely included into the nuclei. Nuclear grooves are also visible (Papanicolaou staining : $a \times 20, c \times 100$; H-E staining $: b \times 20$ ). 


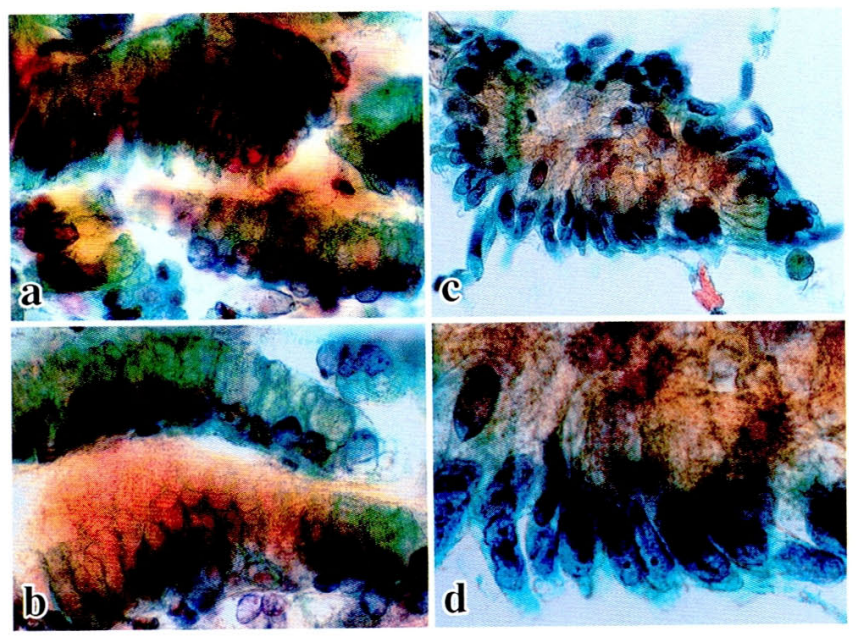

Photo. 1

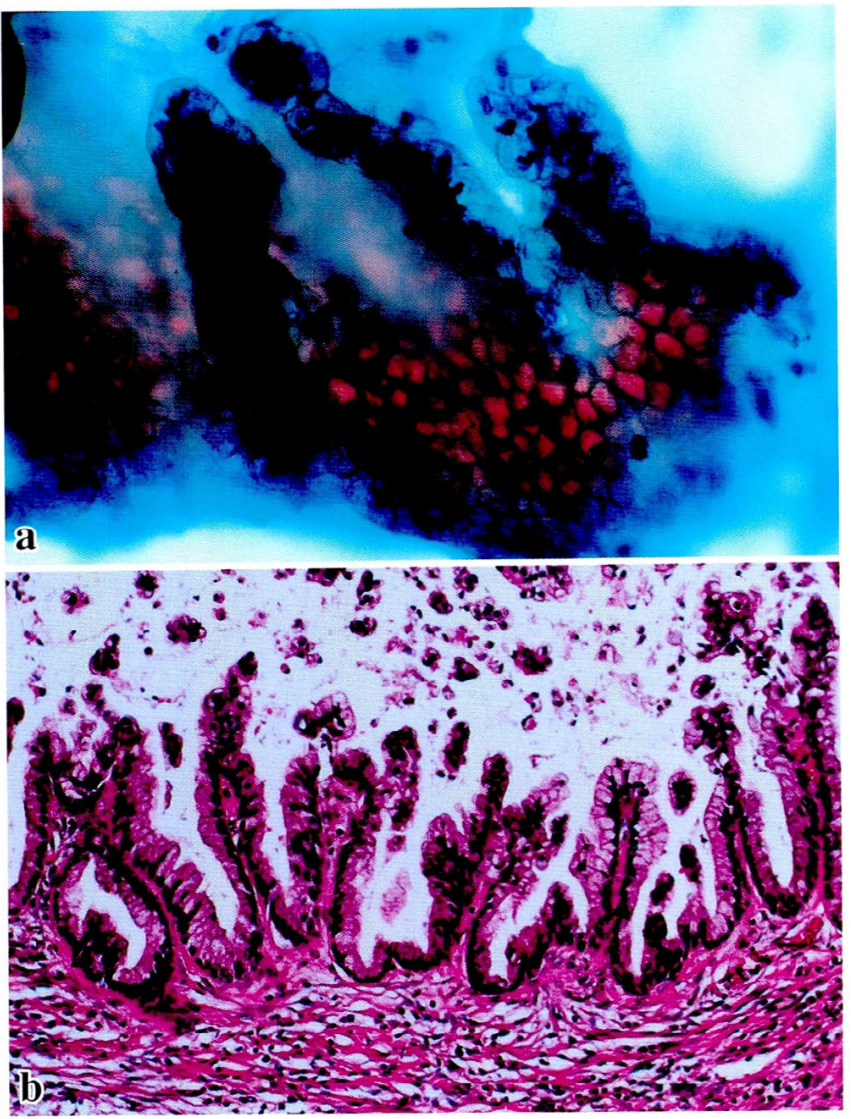

Photo. 3

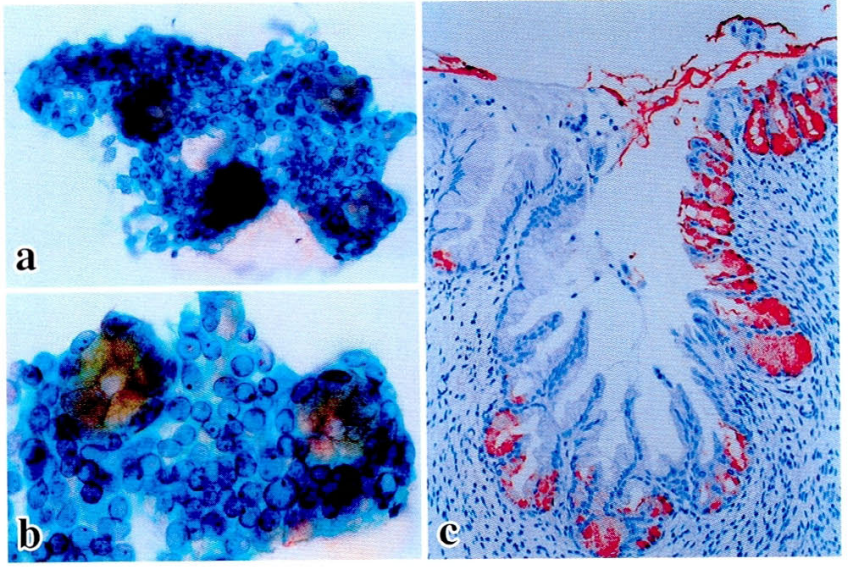

Photo. 2

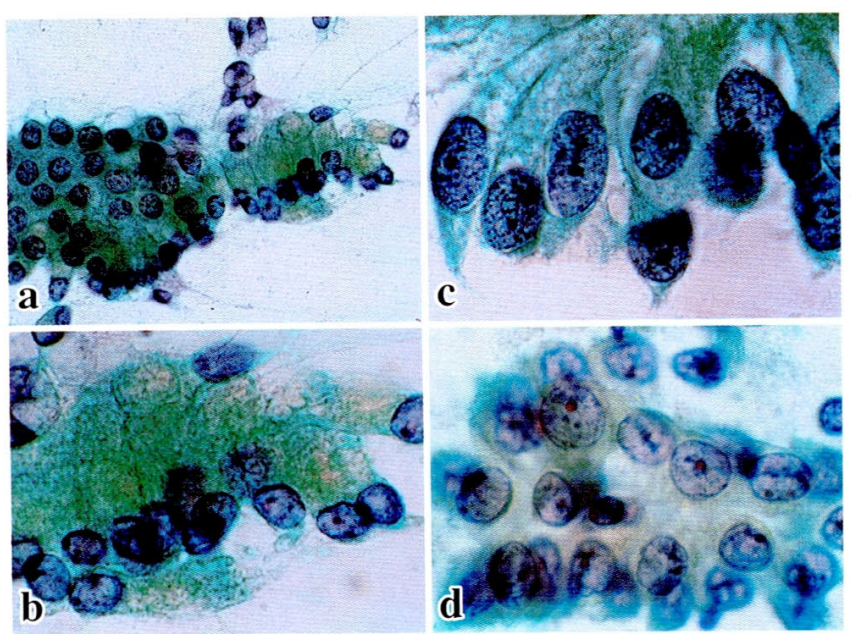

Photo. 4

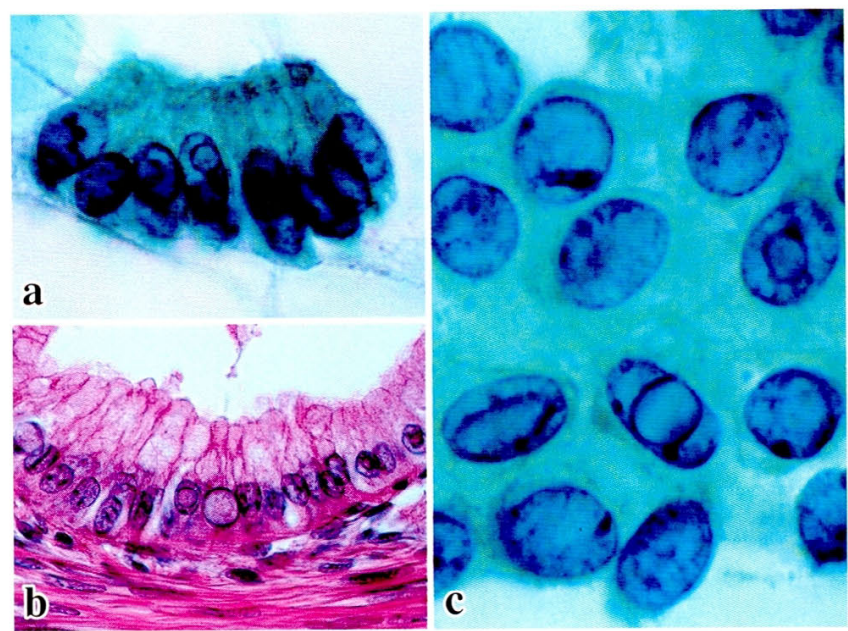

Photo. 5 